\title{
Diversity of Epiphytic Orchids, Hoya, Dischidia and Phorophytes (Host Trees) in Bawean Island Nature Reserve and Wildlife Reserve, East Java, Indonesia
}

\author{
Trimanto $^{1 *}$, Setyawan Agung Danarto ${ }^{1}$ \\ 1) Purwodadi Botanic Garden, Research Center for Plant Conservation and Botanic Garden, Indonesian Institute of Sciences (LIPI)
}

Submitted: 27 January 2020; Accepted: 28 March 2020; Published: 15 August 2020

\begin{abstract}
Bawean Island is a small island located between two islands (Java and Borneo). Geographically, the diversity of plants, especially epiphytic plants on this island is very interesting to be studied. This research aims to investigate the diversity of epiphytic plants, focussing on epiphytic orchids, Hoya and Dischidia in Bawean Island Nature Reserve and Wildlife Reserve. It was conducted through an inventory of epiphytic orchids and hoya growing on host trees. The results showed there were 10 species of epiphytic orchid and 3 species of epiphytic Hoya, and 1 species of Dischidia growing on-location studies. The epiphytic orchids which found in location studies included Phalaenopsis amabilis, Aerides odorata, Cymbidium aloifolium, Dendrobium anosmum, Rhynchostylis retusa, Liparis condylobulbon, Taeniophyllum biocellatum, Cymbidium sp., Eria sp. Orchid species that most often found in the study location was Phalaenopsis amabilis. In addition, this study recorded Taeniophyllum biocellatum as an endemic orchid from Java that was found on this island. The epiphytic Hoya recorded in there, i.e. Hoya diversifolia, H. verticillata, and H. amoena, and also only found 1 species of Dischidia was Dischidia imbricata. There were 12 species of trees as the host trees of epiphytic, i.e. Irvingia malayana, Tectona grandis, Diospyros buxyfolius were the host trees frequently found as the host of the epiphytic plant. Zone 3 as an area of $1 / 3$ basal part of a total length of the branches was the most preferred zone by epiphytic orchids and hoya. The epiphytic orchid and hoya hardly found in Zone 5.
\end{abstract}

Keywords: Bawean, dischidia, epiphyte, hoya, orchid

\section{INTRODUCTION}

Bawean island is one of the small islands located between Borneo and Java islands which leads to the unique biogeography of the island. The diversity of flora and fauna in the Bawean Island consists of Wildlife Reserve with an area of 3,836.6 $\mathrm{Ha}$ and Nature Reserve with an area of $725 \mathrm{Ha}$ (Ministry of Agriculture of Indonesia, 1979). The topography of Bawean Island Wildlife Reserve and Nature Reserve is hilly, mountainous and bumpy. The altitude of the region ranges from 200-687 $\mathrm{m}$ above sea level. Based on the observation of the altitude, the highest altitude of Gunung Lumut Forest was $687 \mathrm{~m}$ above sea level.

The discovery of endemic species such as Bawean deer Axis kublii (Semiadi et al., 2015), new

\footnotetext{
*Corresponding author

Email: triman.bios08@gmail.com

(C) 2020, J. Tropical Biodiversity Biotechnology (CC BY-SA 4.0)
}

species of butterfly Atrophaneuracoon sub. sp. sangkapurae (Maurizio \& Salla, 1992), some endemic birds of Falconiformes and Strigiformes (Nijman, 2004), Javan warty pig Sus verrucosus (Blouch, 1995), Bawean warty pig (Sus blouchi) (Rademaker et al., 2016), indicated that Bawean Island, which is rich with bioresources, can be an interesting subject to be studied. Some inventory studies and assessments on flora biodiversity in Bawean Island have been conducted sporadically in a few past years. Most important and common trees species found in some montane forests are Irvingia malayana, Ficus variegata, and Myristica guatteriaefolia (Danarto and Rahadiantoro, 2015; Trimanto, 2014; Trimanto and Hapsari, 2016).

There is a paucity of data and information on the diversity of epiphytes, especially epiphytic orchids and Hoya in Bawean Island Nature Reserve. Epiphytic plants are plants that grow on the other plants (host trees) but are not parasitic, they can 


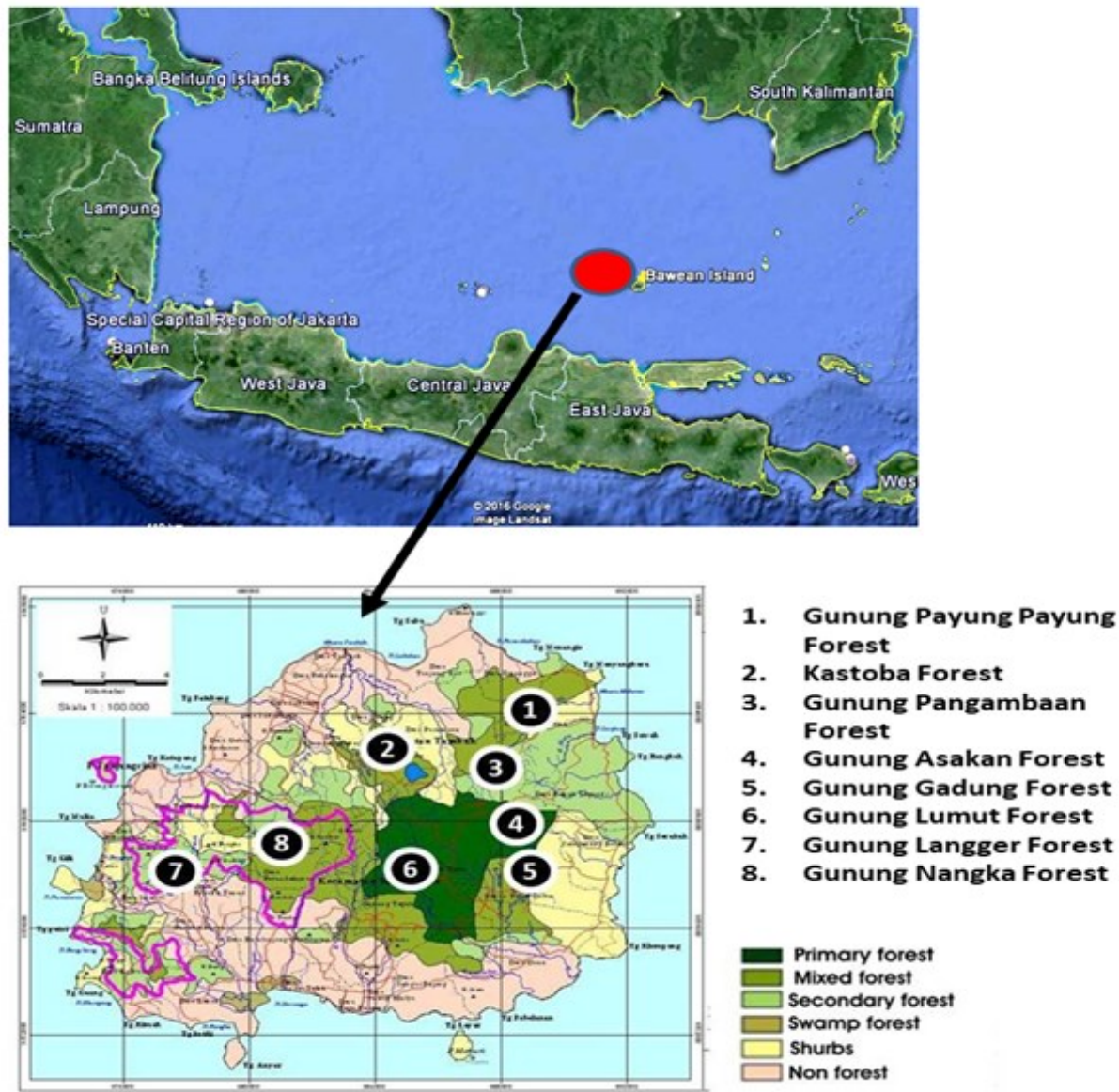

Figure 1. Location of epiphytic plants in Bawean Island, East Java. (Source: Bawean Island Natural Resource Conservation Center and Google Earth 2003).

photosynthesize to provide nutrients for themselves. Ecologically, epiphytes have important roles as they can be used as a bioindicator for the condition of abiotic factors such as humidity, temperature and light intensity in an area. The diversity of epiphytic plants is greatly influenced by microclimates and tree stands (Setyawan, 2000)

This study aims to investigate the epiphytic orchids, Hoya and Dischidia in Bawean Island Nature Reserve and Wildlife Reserve while also can contribute to the scientific documentation and data of the diversity of plants in Bawean Island. This information can be developed into a guide and basis for recommendations on plant conservation policies at the local level as well as modeling for plant conservation strategies on small islands.

\section{METHODS}

\section{Location and Materials}

The study was conducted in 2014 and located in Bawean Island Nature Reserve and Wildlife Reserve (Figure 1). This research used a purposive sampling method covering eight Gunung forest, they are Gunung Langger forest, Gunung Gadung forest, Gunung Asakan forest, Gunung Nangka forest, Gunung Payung-payung forest, Gunung
Pangambaan forest, Kastoba forest, and Gunung Lumut forest with 20 plot for each Gunung forest (each plot's size is $10 \mathrm{~m} \times 10 \mathrm{~m}$ ) were used in this study. Materials used for this study i.e. tally sheets, alcohol $70 \%$, labels, and herbarium sheet while the tools used in this study i.e. GPS, binoculars, and magnifying glasses.

\section{Data Collection}

The method used in this orchid inventory is exploratory. Observations on the epiphytic orchids, Hoya and Dischidia growing on the host trees were conducted. The vertical distribution of the epiphytic orchids and hoya was recorded based on Johansson's methods (1974), which divide host trees into 5 zones (Figure 2):

- Zone 1: Area covering the base of the tree $(1 / 3$ of the main trunk)

- Zone 2: Area from the main trunk of the tree to the first branch ( $2 / 3$ of the main trunk)

- Zone 3: The area covering the basal part of the branching (1/3 part of the total length of the branch)

- Zone 4: The area covering the middle part of the branch $(1 / 3$ of the following middle part)

- Zone 5: Outermost area of branching (1/3 of the 
outermost branching)

The data recorded are the species name of epiphytic plant, the species name of host tree, the number of epiphytic species on host tree, and the number of host tree. For each orchid, Hoya and Dischidia that unidentified in location study needs to be made its herbarium and then the identification process was carried out in Herbarium of Purwodadiensis. An environmental condition such as altitude measured around the habitat of epiphytic plants found at the study site and then recorded on tally sheets.

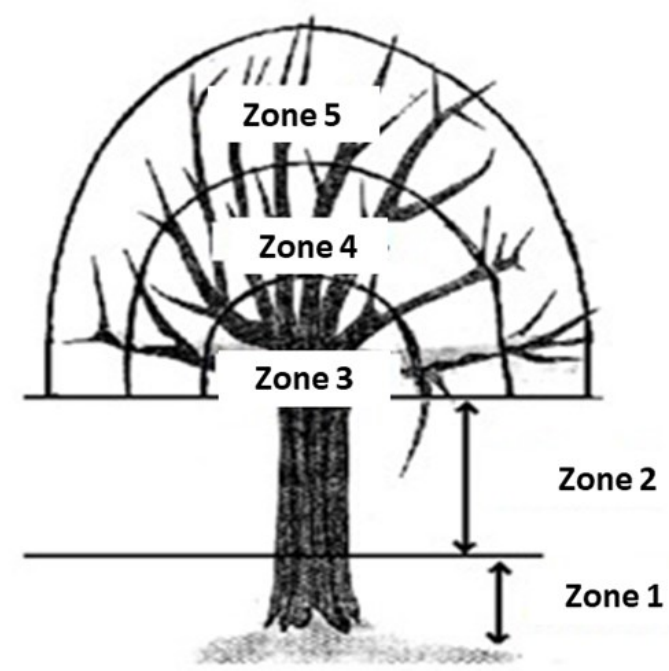

Figure 2. Illustration of host zoning of epiphytic plants by Johansson, 1974. (Source Figure: Aulia and Hakim, 2019).

\section{Data Analysis}

The research measured and analyzed some parameters with a relative abundance of epiphytic ( $\%$ Fo), frequency of phorophyte $(\% \mathrm{Ft})$, the average number of individuals of orchids of each phorophyte species $(\mathrm{Ji} / \mathrm{Jt})$, the average number of epiphytic orchid species on a phorophyte species $(\mathrm{Js} / \mathrm{Jt})$, and the vertical distribution of the orchids on the phorophytes (Nurfadilah, 2016; Yulia \& Budiharta, 2011; Yulia \& Budiharta, 2012).

1) Relative Frequency of Host trees $(\% \mathrm{Ft})$

$$
\% \mathrm{Ft}=\frac{\mathrm{Nt}}{\text { Total number of all phorophytes }} \times 100 \%
$$

where: $\mathrm{Nt}=$ the number of trees in the plot hosting a particular epiphytic species.

2) Abundance of epiphytic plants (\% Fo)

$$
\% \text { Fo }=\frac{\text { No }}{\text { Total number of all epiphytic species }} \times 100 \%
$$

where: $\mathrm{No}=$ the number of individuals of a particular ephypitic species.
3) Average number of individual epiphytic on each host plant (phorophytes)

$=\frac{\mathrm{Ji}}{\mathrm{Jt}}$

where: $\mathrm{Ji}=$ the number of epiphytic individuals. $\mathrm{Jt}=$ the number of individuals of each phorophyte species.

4) The average number of epiphytic species on a phorophyte species

$$
=\frac{\mathrm{Js}}{\mathrm{Jt}}
$$

where: $\mathrm{Ji}=$ the number of epiphytic species. $\mathrm{Jt}=$ the number of individuals of each phorophyte species.

Vertical distribution of orchids (zoning) on the host tree was calculated from the number of species in zone, orchid species on the phorophyte, from the trunk to outer branches in five zones (zone 1, zone 2 , zone 3, zone 4, and zone 5) and by calculating the average number of individuals of epiphytic orchids in each zone. Percentage of epiphytic on every zone was calculated from number present of epiphyte species in each zone/total of present in all zone.

\section{RESULTS AND DISCUSSION}

There were 10 species of epiphytic orchid, 3 species of Hoya and 1 species of Dischidia (Table 1). The results of the present study showed that the number of phorophyte species hosting each epiphytic varied from 1 to 3 species of phorophyte (host trees). Epiphytic plants occurred on a single phorophyte and multiple phorophytes. Some epiphytic plants occurred on a single phorophyte such as Aerides odorata, Dendrobium anosmum, Liparis condylobulbon, Pholidota imbricata, Taeniophyllum biocellatum, Hoya diversifolia, Eria sp. Other Epiphytic plants occurred on multiple phorophytes such as Phalaenopsis amabilis, Cymbidium aloifolium, Rhynchostylis retusa, Hoya verticillata and Dischidia imbricata. The results of the present study were similar to other studies which showed that the number of phorophyte species hosting epiphytic orchids varied from a single to multiple phorophyte species (Nurfadilah, 2016; Adhikari et al., 2012). P. amabilis is an epiphytic orchid with the highest phorophyte species. Some species of epiphytic have not specific phorophyte. Umiyah et al. (2011) reported that epiphytic orchids in Sempu Island have not specific species of host trees but generally grow under canopy cover. 
Table 1. The epiphytic orchids, Hoya, Dischidia and the phorophytes in the Bawean Island Nature Reserve and Wildlife Reserve.

\begin{tabular}{|c|c|c|c|c|c|c|}
\hline No & Species & $\begin{array}{c}\text { Number of } \\
\text { Host Trees } \\
\text { Species }\end{array}$ & Host Trees & Zone & Location & Altitude \\
\hline \multirow[t]{4}{*}{1} & $\begin{array}{l}\text { Phalaenopsis } \\
\text { amabilis }\end{array}$ & 3 & Euonimus javanicus & Zone 3 & Gunung Langgar Forest & $167 \mathrm{~m}$ asl \\
\hline & & & Tectona grandis & Zone 1,2 & Gunung Langgar Forest & $167 \mathrm{~m}$ asl \\
\hline & & & Tectona grandis & $\begin{array}{l}\text { Zone ,1, 2, } 3 \\
\text { and } 4\end{array}$ & Gunung Gadung Forest & $195 \mathrm{~m}$ asl \\
\hline & & & Garcinia dioica & Zone 3 and 4 & Gunung Gadung Forest & $195 \mathrm{~m}$ asl \\
\hline 2 & Aerides odorata & 1 & Leea angulata & Zone 4 and 5 & Gunung Langgar Forest & $167 \mathrm{~m}$ asl \\
\hline \multirow[t]{2}{*}{3} & $\begin{array}{l}\text { Cymbidium } \\
\text { aloifolium }\end{array}$ & 2 & Antidesma petandrum & Zone 2 & Gunung Asakan Forest & $178 \mathrm{~m}$ asl \\
\hline & & & Schleichera oleosa & Zone 2 & Gunung Nangka Forest & $214 \mathrm{~m}$ asl \\
\hline 4 & Cymbidium sp. & 2 & $\begin{array}{l}\text { Tectona grandis } \\
\text { Schleichera oleosa } \\
\text { Schleichera oleosa }\end{array}$ & $\begin{array}{l}\text { Zone } 3 \\
\text { Zone } 1 \\
\text { Zone } 2\end{array}$ & $\begin{array}{l}\text { Gunung Gadung Forest } \\
\text { Gunung Lumut Forest } \\
\text { Gunung Lumut Forest }\end{array}$ & $\begin{array}{l}195 \mathrm{~m} \text { asl } \\
423 \mathrm{~m} \text { asl } \\
423 \mathrm{~m} \text { asl }\end{array}$ \\
\hline 5 & $\begin{array}{l}\text { Dendrobium } \\
\text { anosmum }\end{array}$ & 1 & Tectona grandis & Zone 4 and 5 & Kastoba Forest & $256 \mathrm{~m}$ asl \\
\hline 6 & Rhynchostylis retusa & 2 & $\begin{array}{l}\text { Diospyros buxifolia } \\
\text { Diospyros buxifolia } \\
\text { Syzygium sp }\end{array}$ & $\begin{array}{l}\text { Zone } 2,3 \\
\text { Zone } 3 \\
\text { Zone } 1\end{array}$ & $\begin{array}{l}\text { Gunung Nangka Forest } \\
\text { Gunung Nangka Forest } \\
\text { Gadung Mount Forest }\end{array}$ & $\begin{array}{l}215 \mathrm{~m} \text { asl } \\
215 \mathrm{~m} \text { asl } \\
195 \mathrm{~m} \text { asl }\end{array}$ \\
\hline 7 & $\begin{array}{l}\text { Liparis } \\
\text { condylobulbon }\end{array}$ & 1 & Irvingia malayana & Zone 3 and 4 & Gadung Mount Forest & $195 \mathrm{~m}$ asl \\
\hline 8 & Pholidota imbricata & 1 & Irvingia malayana & Zone $1,3,4$ & Pangambaan Mount Forest & $266 \mathrm{~m}$ asl \\
\hline 9 & $\begin{array}{l}\text { Taeniophyllum } \\
\text { biocellatum }\end{array}$ & 1 & Canarium birsutum & Zone 3 and 4 & Hutan Kastoba & $285 \mathrm{~m}$ asl \\
\hline 10 & Eria sp. & 1 & Tectona grandis & Zone 4 & Pangambaan Mount Forest & $266 \mathrm{~m}$ asl \\
\hline 11 & Hoya diversifolia & 1 & Ficus variegate & $\begin{array}{l}\text { Zone 1, } 2 \\
\text { and } 3\end{array}$ & $\begin{array}{l}\text { Payung-payung Mount } \\
\text { Forest }\end{array}$ & $197 \mathrm{~m}$ asl \\
\hline 12 & Hoya amoena & 1 & Ficus variegata & Zone 1 and 2 & Gunung Nangka Forest & $207 \mathrm{~m}$ asl \\
\hline 13 & Hoya verticillata & 2 & $\begin{array}{l}\text { Euria nitida } \\
\text { Ficus variegata }\end{array}$ & $\begin{array}{l}\text { Zone } 3 \\
\text { Zone } 4\end{array}$ & $\begin{array}{l}\text { Kastoba Forest } \\
\text { Kastoba Forest }\end{array}$ & $\begin{array}{l}295 \mathrm{~m} \text { asl } \\
295 \mathrm{~m} \text { asl }\end{array}$ \\
\hline \multirow[t]{2}{*}{14} & Dischidia imbricata & 2 & Antidesma petandrum & Zone 3 & Gunung Nangka Forest & $207 \mathrm{~m}$ asl \\
\hline & & & $\begin{array}{l}\text { Diospyros buxifolia } \\
\text { Diospyros buxifolia }\end{array}$ & $\begin{array}{l}\text { Zone } 4 \\
\text { Zone } 3\end{array}$ & $\begin{array}{l}\text { Gunung Nangka Forest } \\
\text { Gunung Nangka Forest }\end{array}$ & $\begin{array}{l}207 \mathrm{~m} \text { asl } \\
207 \mathrm{~m} \text { asl }\end{array}$ \\
\hline
\end{tabular}

Epiphytic Orchids, Hoya and Dischidia in Bawean Island Nature Reserve and Wildlife Reserve

The most abundant epiphytic plant in Bawean Island Nature Reserve and Wildlife Reserve is Phalaenopsis amabilis that most often found in Tectona grandis. There were 3 species of host tree of $P$. amabilis, i.e. Tectona grandis, Euonimus javanicus, and Garcinia dioica. Besides that this species can grow in zone 1, 2, 3, 4 of host trees. The presence of Phalaenopsis amabilis is a species of epiphytic orchid species (Fig. 3a) indicates that the orchids are not only found on Borneo and Java islands. There is an abundance level of orchid species availability both in distribution and population on Bawean Island Nature Reserve. P. amabilis is a species of orchid having the most significant relative abundance $(22.5 \%)$ compared to other epiphytic plants (Table 2). Phalaenopsis amabilis as known as Anggrek Bulan in local names as the most preferable orchid by the community due to the beauty of flowers. This genus has a wide distribution in tropical forests (Fandani et al., 2018), which is found in several areas including Sempu Island (Yulia, 2010), Batuputih Nature Park in Sulawesi with an altitude of 52-102 $\mathrm{m}$ above sea level (Yubu et al., 2018), but can also be found in the middle altitude such as Petungkriyono Forest in Pekalongan with an altitude of 700-900 $\mathrm{m}$ above sea level (Mardiyana $e t$ al., 2019).

Rhynchostylis retusa and Dischidia imbricata is the second abundant epiphytic plant in the study locations with relative diversity was $10 \%$. R retusa that can grow on zone 1,2,3, and well adapt in 2 species of host tree i.e. Diospyros buxifolia and Sysygium sp. This species can be found in several locations that indicated it has well adaptation in different host trees and habitat. Dischidia imbricata also can grow in 2 species of host trees (Antidesma 


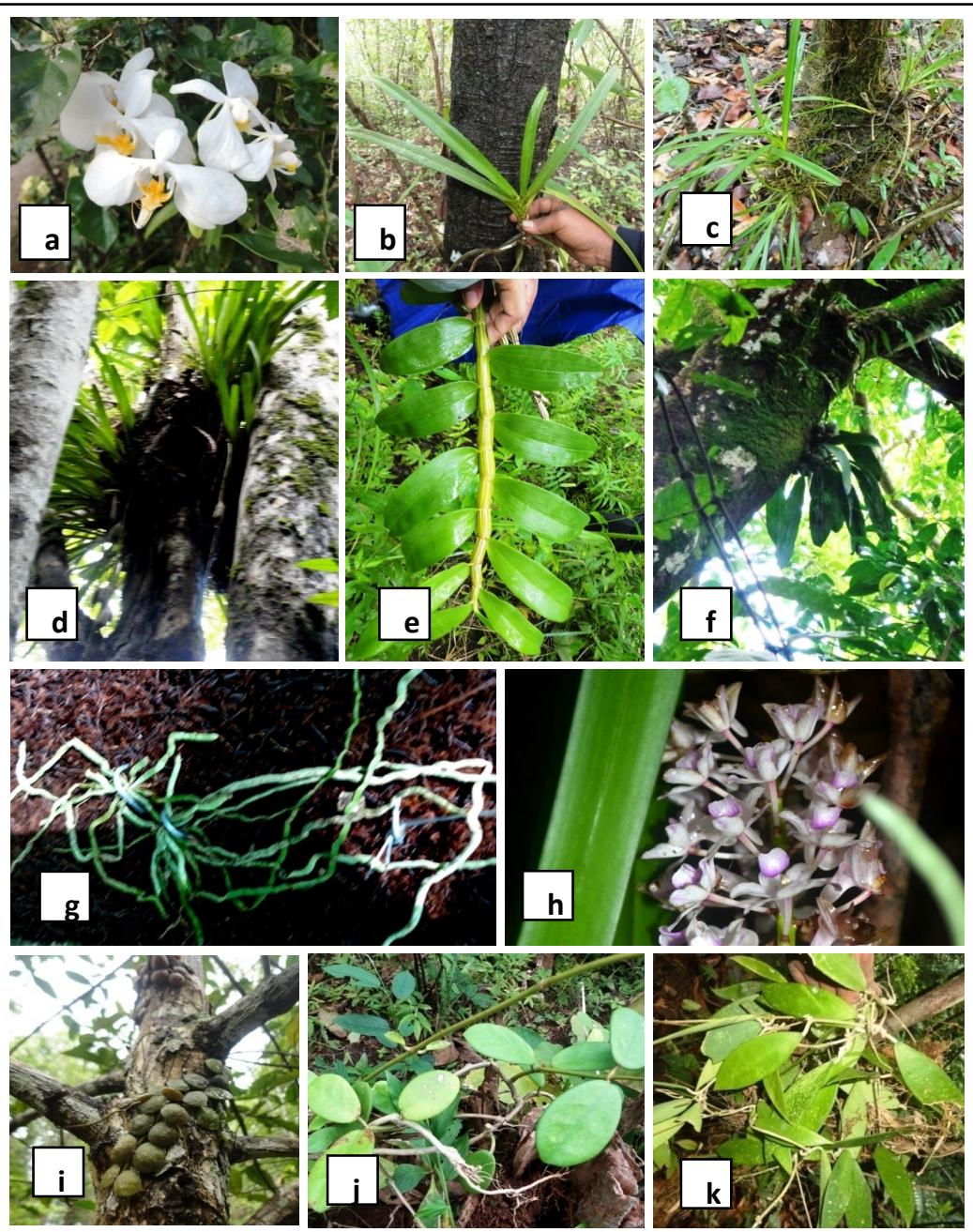

Figure 3. Diversity of Orchid, Hoya and Dischidia epiphyte. a) Phalaenopsis amabilis, b) Aerides odorata, c) Cymbidium aloifolium, d) Cymbidium sp., e) Dendrobium anosmum, f) Pholidota imbricata, g) Taeniophyllum biocellatum, h) Rhynchostylis retusa, i) Dischidia imbricata, j) Hoya diversifolia, k) Hoya verticillata.

petandrum and Diospyros buxifolia) on zone 3 and 4. D. imbricata is an adaptable plant that has a small leaf to reduce transpiration which supports its growth in low humidity and low water availability.

Some other species of epiphytic orchids found on Bawean Island were Aerides odorata, Cymbidium aloifolium, Dendrobium anosmum, Pholidota imbricata, and Pholidota imbricata. Compared with other studies of diversity epiphytic orchids on Java, the richness of epiphytic orchids on Bawean Island has almost the same number species of epiphytic orchids compared with other location on Java such as Sempu Island Nature Reserve which consists of 10 species, Gunung Lamongan forest area consisting of 7 species, Penanggungan forest area consisting of 9 species (Yulia, 2010), and Gunung Tukung Gede Nature Reserve consisting of 9 species (Sulistiarini and Djarwaningsih, 2017). Sadili (2019), reported that there were only 4 species which found on Sempu Island. However, the species of epiphytic orchids on Bawean Island have lower numbers than the number of orchid species found in the high altitude such as Semarang Gebugan Nature Reserve which consists of 11 species of orchids (Farokhah et al., 2018), and the Conservation Area of Senduro which has 39 species of epiphytic orchids (Febriandito and Soetopo, 2019). This illustrates that Bawean Island has unique environmental conditions due to its location in a unique geographical location between Java and Borneo. Orchids on Bawean Island are priceless germplasm so that it need attention and preservation from the government.

One of the endemic orchids found on Java Island is Taeniophyllum biocellatum (Figure 3g.). On Bawean Island Nature reserve this species only found in 1 host tree (Canarium birsutum) with 5\% abundance. The population of this species is threatened due to forest exploitation. The discovery of $T$. biocellatum indicates that the presence of endemic orchids in Java is also spread in Bawean Island so that it can be seen that Bawean Island reflects as Java lowland forests. This species is dominants in Sempu Island and grow optimally in 
sheltered condition (Sadili, 2019). Leaves of $T$. biocellatum are absent but they have green roots that contain chloroplasts. The presence of chloroplasts confirmed in the anatomical roots characters of $T$. biocellatum (Nurfadilah et al., 2016). There must be conserve of the $T$. biocellatum in its natural habitat while maintaining the presence of trees serving as the host for the epiphytic orchid. T. biocellatum is very difficult to conserve outside its habitat (ex situ) that was indicated by poor adaptation in the acclimatization process in Purwodadi Botanic Garden.

Table 2. Abundance of epiphytic species in Bawean Island Nature Reserve and Wildlife Reserve.

\begin{tabular}{|c|c|c|c|c|c|}
\hline No & $\begin{array}{l}\text { Species of } \\
\text { Epiphyte }\end{array}$ & $\mathrm{Nt}$ & No & $\% \mathrm{Ft}$ & $\% \mathrm{Fo}$ \\
\hline 1 & $\begin{array}{l}\text { Phalaenopsis } \\
\text { amabilis }\end{array}$ & 4 & 9 & 16 & 22.5 \\
\hline 2 & Aerides odorata & 1 & 2 & 4 & 5 \\
\hline 3 & $\begin{array}{l}\text { Cymbidium } \\
\text { aloifolium }\end{array}$ & 1 & 1 & 4 & 2.5 \\
\hline 4 & Cymbidium sp. & 3 & 3 & 12 & 7.5 \\
\hline 5 & $\begin{array}{l}\text { Dendrobium } \\
\text { anosmum }\end{array}$ & 1 & 2 & 4 & 5 \\
\hline 6 & $\begin{array}{l}\text { Rhynchostylis } \\
\text { retusa }\end{array}$ & 3 & 4 & 12 & 10 \\
\hline 7 & $\begin{array}{l}\text { Liparis } \\
\text { condylobulbon }\end{array}$ & 1 & 2 & 4 & 5 \\
\hline 8 & Pholidota imbricata & 1 & 3 & 4 & 7.5 \\
\hline 9 & $\begin{array}{l}\text { Taeniophyllum } \\
\text { biocellatum }\end{array}$ & 1 & 2 & 4 & 5 \\
\hline 10 & Eria sp. & 1 & 1 & 4 & 2.5 \\
\hline 11 & Hoya diversifolia & 1 & 3 & 4 & 7.5 \\
\hline 12 & Hoya amoena & 1 & 2 & 4 & 5 \\
\hline 13 & Hoya verticillata & 2 & 2 & 8 & 5 \\
\hline 14 & Dischidia imbricata & 4 & 4 & 16 & 10 \\
\hline
\end{tabular}

$\mathrm{Nt}=$ The number of treesin the plot hosting a particular epiphytic species.

No $=$ The number of individuals of a particular epiphytic species within the plot.

$\% \mathrm{Ft}=$ Relative frequency of phorophytes.

$\% \mathrm{Fo}=$ Abundance of epiphytic plants.

There are only 3 species of Hoya and 1 species of Dischidia that recorded in Bawean Island i.e. Hoya diversifolia (Figure 3j), H. verticillata (Figure 3k), H. amoena, Dischidia imbricata were found in the forest of Bawean Island with abundance ranges between 5$10 \%$. Compared with other locations, the diversity of Hoya in Bawean Island is relatively low. The number of Hoya species in other location including Bodogol Conservation Area recorded 6 species (Sulaeman et al., 2019), Belitung Island recorded 5 species (Rahayu et al., 2018), Gunung Gede Pangrango recorded 10 species (Rahayu, 2012), Sumatra included 41 species and 2 subspecies
(Rahayu and Rodda, 2019), and Borneo included 34 species (Lamb and Rodda, 2016).

Hoya is a succulent plant having the ability to grow on less moist or dry conditions. Hoya can also live as terrestrial plants, but most of them were found in nature as epiphytic plants. It has a sticky root on the trunk, which is used to attach itself to the host tree. Hoya plants are also called "wax plants" due to the waxy appearance of their leaves or flowers (Panajon et al., 2016). The leaf characteristic of the three species of hoya is succulent, which means it can store water in its organs (Fahn, 1991), which function to adapt to extreme conditions (Keraudren, 1990). Succulence also associated with ecophysiological strategies and occurs in plants that have evolved in many different environments condition (Griffiths \& Males, 2017). A previous study from Sulaeman et al. (2019) in Bodogol Conservation Area reported that air humidity and canopy cover is abiotic factors that most influencing Hoya's existence. The presence of Hoya campalunata has the highest correlation with wind speed and air temperature. Hoya multiflora, Hoya vitellinoides, Hoya hasseltii, and Hoya imperalis have positively correlated with air humidity and canopy cover.

\section{Host Trees (Phorophyte) Species}

There were 12 species recorded as host plants of epiphytic species. The preferable tree species as a host tree by the epiphytic species are Tectona grandis, Irvingia malayana and Diospyros buxifolia (Table 3). T. grandis had the highest species richness of epiphytic orchids, 4 species had been recorded growing on this phorophyte. Tectona grandis or often referred to as teak trees is also an orchid host tree in Bawean Nature Reserve. T. grandis is cultivated by people surrounding the forest as a community forest (butan rakyat). Teak (Tectona grandis) is one of the most economic tropical hardwood which has naturally distributed from India through Myanmar, Laos, and Thailand (Deb et al., 2017). There were 4 species of orchids attaching on teak trees, i.e. Phalaenopsis amabilis, Dendrobium anosmum and Cymbidium sp., and Eria sp. Among other species, teak is the preferable tree by epiphytic plants. In teak trees, there are often found seedlings of $P$. amabilis and $D$. anosmum in their trunk. This proves that $T$. grandis is a suitable host for epiphytic orchid growth. At the Meru Betiri National Park in East Java, T. grandis is a tree that is often seen as a host for epiphytic orchids among other trees (Puspitaningtyas, 2007). Orchid seeds require special conditions to germinate because of mycoheterotrophic character which during the growth stage, the seeds have a depend on fungi as a source of carbohydrates for orchid growth (Dearnaley et al., 2016). 
Table 3. Host trees (phorophytes) in Bawean Island with these parameters.

\begin{tabular}{|c|c|c|c|c|c|c|}
\hline $\mathrm{No}$ & Host Trees & $\mathrm{Jt}$ & Js & $\mathrm{Ji}$ & $\mathrm{Js} / \mathrm{Jt}$ & $\mathrm{Ji} / \mathrm{jt}$ \\
\hline 1 & $\begin{array}{l}\text { Antidesma } \\
\text { petandrum }\end{array}$ & 3 & 2 & 3 & 0.67 & 1.00 \\
\hline 2 & $\begin{array}{l}\text { Canarium } \\
\text { birsutum }\end{array}$ & 1 & 1 & 1 & 1.00 & 1.00 \\
\hline 3 & $\begin{array}{l}\text { Diospyros } \\
\text { buxifolia }\end{array}$ & 4 & 2 & 5 & 0.50 & 1.25 \\
\hline 4 & $\begin{array}{l}\text { Euonimus } \\
\text { javanicus }\end{array}$ & 1 & 1 & 1 & 1.00 & 1.00 \\
\hline 5 & Euria nitida & 1 & 1 & 1 & 1.00 & 1.00 \\
\hline 6 & Ficus variegate & 2 & 2 & 3 & 1.00 & 1.50 \\
\hline 7 & $\begin{array}{l}\text { Irvingia } \\
\text { malayana }\end{array}$ & 2 & 2 & 5 & 1.00 & 2.50 \\
\hline 8 & Leea angulata & 1 & 1 & 1 & 1.00 & 1.00 \\
\hline 9 & $\begin{array}{l}\text { Schleichera } \\
\text { oleosa }\end{array}$ & 3 & 2 & 3 & 0.67 & 1.00 \\
\hline 10 & Sysygium sp. & 1 & 1 & 1 & 1.00 & 1.00 \\
\hline 11 & $\begin{array}{l}\text { Tectona } \\
\text { grandis }\end{array}$ & 5 & 4 & 10 & 0.80 & 2.00 \\
\hline 12 & $\begin{array}{l}\text { Garcinia } \\
\text { dioica }\end{array}$ & 1 & 1 & 1 & 1.00 & 1.00 \\
\hline $\mathrm{i} / \mathrm{Jt}$ & $\begin{array}{l}=\text { Number of } 1 \\
=\text { Number of } \\
=\text { Number of } \mathrm{i} \\
=\text { Average nu } \\
\text { plants. } \\
=\text { Average nur } \\
\text { host plants. }\end{array}$ & $\begin{array}{l}\text { phyt } \\
\text { ivid }\end{array}$ & $\begin{array}{l}\text { plan } \\
\text { epir }\end{array}$ & $\begin{array}{l}\text { becic } \\
\text { tic s }\end{array}$ & $\begin{array}{l}\text { plants } \\
\text { cies. } \\
\text { ecies i }\end{array}$ & host \\
\hline
\end{tabular}

The second preferable tree species as a host tree is Diospyros buxifolia. This tree is the host of the Rhynchostylis retusa and Dischidia imbricata. D.buxifolia is suitable for the growth of orchids and hoya due to its trunk surface has a rough character which makes it easy for epiphytic roots to stick to stem surface. Dischidia imbricata is an epiphytic plant that has a small root character, so it requires a suitable stem to be able to attach the roots. Genus of Diospyros is the largest, most widely distributed, and economically trees of Ebenaceae family (Tang et al., 2019). D. buxifolia has branching with a circular arrangement at interval $15-20 \mathrm{~cm}$. This species has black coloured in the stem, smooth surface, and shallow grooved (Kinho, 2013). This circular branching arrangement allows sunlight to enter the canopy and affect the air humidity level around the canopy that suitable for the growth of R. retusa and D. imbricata.

The third preferable tree species as a host tree is Irvingia malayana. The largest individual numbers of epiphytic orchids was also found in I. malayana. This species is suitable for epiphytic growth, especially orchids, i.e. Liparis condylobulbon and Pholidota imbricata. I. malayana is the dominant tree in the Bawean Island forest with a large diameter. Its called in local name as "red wood" (bahasa: kayu merab). In addition, this species also has a reasonably large wood density of $0.84 \mathrm{~g} \mathrm{~cm}-3$ (Zanne et al., 2009). Irvingia malayana fruit is a favorite feed of endemic deer (Axis kublii) of Bawean Island. The presence of endemic deer (Axis kublii) is expected to play a role in the distribution of seeds of the species of Irvingia malayana (Trimanto, 2014). This deer knew as Critically Endangered status on the IUCN Red List (Rahman et al., 2017a; 2017b). Based on the inventory of orchid in East Borneo, Irvingia malayana is the most tree for a host of epiphytic plants. There are at least 10 species of epiphytes growing in Irvingia malayana. It indicates that $I$. malayana has characteristics of having a suitable trunk surface for epiphytic growth (Trimanto \& Sofiah, 2018).

One of the host trees is Euonimus javanicus found in Gunung Lumut Forest. Bark surface of E. javanicus becomes a growing place of moss making it suitable for epiphytic plants. $P$. amabilis grew on this bark. In other studies, the condition of the stem that stuck by Hoya purpureofusca has a rather to very rough skin stem. The surface of the bark of the host tree covered $20-70 \%$ by moss so that it can support the growth of H. Purpureofusca (Hidayat et al., 2012). Schleicera oleosa (Kesambi) is a host tree by Cymbidium aloifolium. S. oleosa can reach up to $40 \mathrm{~m}$ in height, up to $2 \mathrm{~m}$ in diameter. Skin bark was smooth, gray, and wrinkled (Suita, 2012), that suitable for the growth of epiphytic orchids. Morphology of trees influencing the presence of epiphytic plants such as stem diameter, crown and branch shape. The presence of epiphytic plants is also influenced by microclimate, while the microclimate of the forest depends on vegetation conditions such as crown density and shape crown. Skin bark of a tree with rough and cracked surface, and has many indentation and scar will be filled by humus which suitable for epiphytic plants (Sujalu, 2017).

Vertical Distribution of Epiphytic Orchids, Hoya and Dischidia on Host Trees (Phorophyte) Species

The present study showed a range of vertical distribution of epiphytic orchid, Hoya and Dischidia from zone 1 to zone 5 (Table 4). The epiphytic orchid grew on zone 1 to zone 5, while epiphytic Hoya grew on zone 1 to zone 4, and epiphytic Dischidia grow on zone 3 to zone 4 . The most abundant orchid Phalaenopsis amabilis, was found to have the widest vertical distribution ranging from zone 1 to zone 4. Most epiphytic orchid species grew on zone 3 and zone 4. A small number of orchid species occurred on the trunk (only two orchids species grew on zone 5). The epiphytic Hoya most grew on zone 1-3, but only 1 species grew on zone 4. Hoya was not found in zone 5. The 
epiphytic Dischidia only grew on zone 3 and 4 . Based on other studies epiphytic orchid in Coban Trisula and Mexico, where vascular epiphyte abundance was higher in zone 3-5 (tree crown) than in zone 1-2 (along the trunk) due to enter light intensity nearby the tree crown (Nurfadilah, 2016; Manzano et al., 2014), but in Bawean Island forest, the abundance of epiphytic orchid is the least on zone 5 compare to other zones. Two species of orchid that grew on zone 5 is Aerides odorata and Dendrobium anosmum.

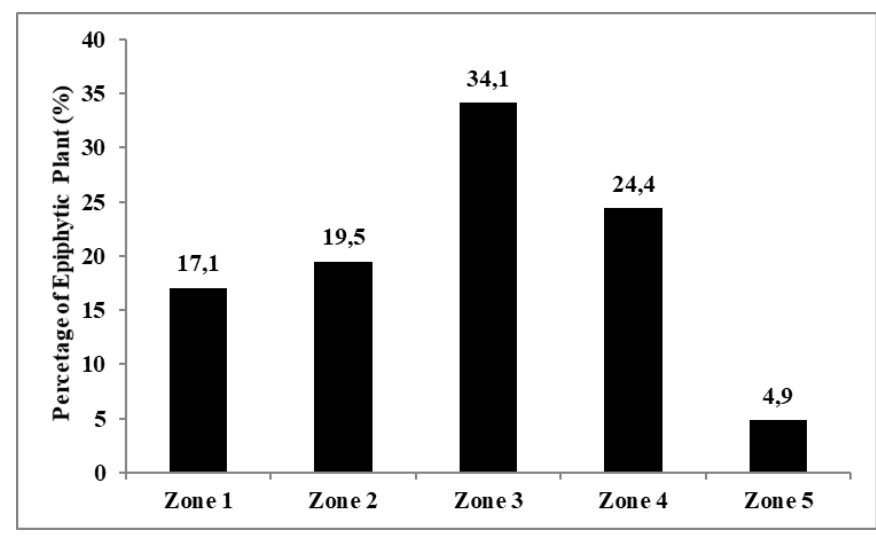

Figure 4. Comparison of the frequency of epiphytic presence in the phorophytes zone.

The presence of epiphytes was often grown on zone 3 and 4 (Figure 4). Zone 3 is the central area or in the main trunk branching area of phorophytes that has an optimum level of light intensity for epiphytic plants growth. Zone 3 is the first branching of a tree, which provides sufficient surface area to stick the epiphytic roots. Epiphytic orchids were mostly found in this zone. The highest frequency of epiphytic plant (Orchids, Hoya, and
Dischidia) were present in zone 3 with percentage was $34.1 \%$. There were 9 species that grew on this zone. Zone 3 provides optimum environmental conditions for epiphytes growth. In the branching area, it usually contains more humus subtract and other epiphytic plants such as ferns so it provides enough moisture for epiphytes growth. Skin roughness and substrate fields serve as important factors that influence the abundance level of epiphytic orchids (Manzano, 2014). The second largest percentage zone is zone 4, it was also about 9 species grew on zone 4 with percentage were 24.4 $\%$. The presence of epiphytic plants on phorophytes is determined by branches containing humus and moisture substrate that are accumulated from other epiphytic plants such as fern. Humus and moisture substrate in phorophytes supporting the growth of epiphytic plants. In this case, Discidhia imbricata only grew on zone 3 and zone 4 . Zone 1 is the lowest or base area of the tree $(1 / 3$ of the main trunk). This zone has a low intensity of light and very close to the soil surface. Zone 1 is the habitat transition for epiphytic plants that previously as terrestrial plants and then change as epiphytic plants. At the beginning of its growth, Hoya grows and develops on the soil surface and then spread to the trunk surface of host trees. This zone is very suitable for Hoya, which starts to adapt from terrestrial habitat (soil) to an epiphyte habitat. In Zone 1, it is also found 4 species of orchids and 2 species of Hoya, i.e. Pholidota imbricata, Cymbidium sp., Rhynchostylis retusa, Phalaenopsis amabili, Hoya diversifolia and $H$. amoena. Zone 2 has moderate light intensity so that some of the species can growth optimum in this zone. Zone 2 also has a greater surface area for epiphyte root. In Zone 2 , the percentage of

Table 4. Zones of the occurrence of epiphytic orchids, Hoya and Dischidia on their phorophytes and the number of individuals in each zone.

\begin{tabular}{|c|c|c|c|c|c|c|}
\hline No & Species of Epiphyte & Zone 1 & Zone 2 & Zone 3 & Zone 4 & Zone 5 \\
\hline 1 & Phalaenopsis amabilis & 2 & 3 & 2 & 2 & \\
\hline 2 & Aerides odorata & & & & 1 & 1 \\
\hline 3 & Cymbidium aloifolium & & 2 & & & \\
\hline 4 & Cymbidium sp. & 1 & 1 & 1 & & \\
\hline 5 & Dendrobium anosmum & & & & 1 & 1 \\
\hline 6 & Rhynchostylis retusa & 1 & 1 & 2 & & \\
\hline 7 & Liparis condylobulbon & & & 1 & 1 & \\
\hline 8 & Pholidota imbricate & 1 & & 1 & 1 & \\
\hline 9 & Taeniophyllum biocellatum & & & 1 & 1 & \\
\hline 10 & Eria sp. & & & & 1 & \\
\hline 11 & Hoya diversifolia & 1 & 1 & 1 & & \\
\hline 12 & Hoya amoena & 1 & 1 & & & \\
\hline 13 & Hoya verticillata & & & 1 & 1 & \\
\hline \multirow[t]{2}{*}{14} & Dischidia imbricate & & & 3 & 1 & \\
\hline & $\begin{array}{l}\text { Total number of epiphytic } \\
\text { plant }\end{array}$ & 7 & 8 & 14 & 10 & 2 \\
\hline
\end{tabular}


epiphytes presence is large with a percentage of $19.5 \%$. In location studies, there were 3 species of orchids and 2 species of hoya grows on zone 2 i.e. Phalaenopsis amabilis, Cymbidium aloifolium, Rhynchostylis retusa, Hoya diversifolia and Hoya amoena. Zone 2 is also a suitable habitat for Cymbidium aloifolium which is proven that orchid species were rarely found in the upper zone of the phorophytes.

The smallest presence of epiphytes in zone 5 (the outermost area of the branching) due to this zone has the smallest surface area. There were only 2 species of epiphytes present in this zone due to this zone is not sheltered by a crown of phorophytes, i.e. Aerides odorata and Dendrobium anosmum. This zone has high light intensity and low air humidity level because of the character forest of Bawean Island is lowland and dry so that not supporting for growth of epiphytic plants in this zone. Zone 5 is actually the safest area to avoid epiphytic plants from human exploitation. This zone is blocked by small branches and leaves.

\section{Implication for Conservation}

It is necessary to maintain the sustainability of forest trees in order to protect it from exploitation because trees are host plants of various epiphytic plants in the forest. Preservation of forest trees and epiphytic plants can involve the local community. Orchids, Hoya, and Dischidia on Bawean Island are sources of germplasm that must be conserved because these epiphytic plants have genetic sources that may be different from similar epiphytic plants in other regions.

\section{CONCLUSION}

There were 10 species of epiphytic orchids, 3 species of Hoya, and 1 species of Dischidia that have been recorded in Bawean Island Nature Reserve and Wildlife Reserve. The most commonly found of epiphytic orchid in location studies is Phalaenopsis amabilis. There were 12 species of trees as the hosts of epiphytic plants. Tectona grandis, Irvingia malayana, and Diospyros buxifolia were the trees that often found as the host of epiphytic plants. Zone 3 is the area covering the basal part of the branching $(1 / 3$ part of the total length of the branch) serves as the zone which is the most often found epiphytic plants. The least epiphytic presence is found in Zone 5.

\section{REFERENCES}

Adhikari, Y.P., Fischer, H.S., Fischer, A., 2012, Host tree utilization by epiphytic orchids in different land-use intensities in Kathmandu Valley, Nepal, Plant Ecology 213, 393-412.
Aulia, A. N., \& Hakim, L., 2019, Technique for sustainable development along trisula waterfall (Coban Trisula)-Ranu Pani, Bromo Tengger Semeru National Park: a case of epiphytic orchid conservation, Journal of Environmental Engineering and Sustainable Technology 6(1), 16-22.

Blouch R.A., 1995, Conservation and research priorities for threatened Suids of South and Southeast Asia, IBEX J.M.E. 3, 21-25.

Danarto S.A., \& Rahadiantoro, A., 2015, Eksplorasi tumbuhan di Pulau Bawean, Gresik, Jawa Timur [Plant exploration in Bawean Island,Gresik-East Java]. Proceedings of National Conference of Indonesian Biodiversity Community 1 (5), 974-979.

Dearnaley, J., Perotto, S., \& Selosse, M. A., 2016, 'Structure and development of orchid mycorrhizas', in F.Martin (eds), Molecular Mycorrbizal Symbiosis, pp.63-86, John Wiley \& Sons, Canada.

Deb, J. C., Phinn, S., Butt, N., \& McAlpine, C. A., 2017, Climatic-induced shifts in the distribution of teak (Tectona grandis) in tropical Asia: implications for forest management and planning, Environmental management 60(3), 422435.

Farokhah, T., Utami, S., \& Jumari, J., 2018, Keragaman dan kelimpahan anggrek di Cagar Alam Gebugan, Semarang, Indonesia Diversity and abundance of orchids at Gebugan Nature Reserve in Semarang, Indonesia]. Biosaintifika 10(2), 284-290.

Fandani, H. S., \& Mallombasang, S. N., 2018, Keragaman anggrek pada beberapa penangkaran di Desa Ampera dan Desa Karunia, Kecamatan Palolo, Kabupaten Sigi Diversity of orchid in some of captivity in Ampera and Karunia Village, Palolo Subdistrict, Sigi District]. Jurnal Warta Rimba 6(3), 14-20.

Febriandito, P.D., \& Soetopo, L., 2019, Exploration of epiphytic orchid diversity at Senduro Conservation Area II, Ireng-Ireng Block, Bromo Tengger Semeru National Parks, East Java, Plantropica 3(2), 68-76.

Griffiths, H., \& Males, J., 2017, Succulent plants, Current Biology 27(17), 890-896.

Hidayat, S., Rahayu, S., \& Ningtyas, K, 2012, Analisis vegetasi habitat hoya Hoya purpureofusca hook.f. di Resort Selabintana, Taman Nasional Gunung Gede Pangrango [Vegetation analysis of habitat Hoya purpureofusca hook.f. in Selabintana Resort, Gunung Gede-Pangrango National Park]. Berita Biologi 11(1), 103-110. 
Johansson D.R., 1975, Ecology of epiphytic orchids in West African rainforests. Am Orchid Soc Bull 44, 125-136.

Keraudren-Aymonin, M., 1990, 'Epidermal and anatomical features of the succulent xerophytic cucurbitaceae of Madagascar: adaptive and phylogenetic aspects' in D.M. Bates, R.W. Robinson, \& C. Jeffrey (eds.), Biology and Utilization of the Cucurbitaceae, pp. 239-247, Cornell University Press, London.

Kinho, J., 2013., Restoring the glory of ebony in North Sulawesi, Balai Penelitian Kehutanan Manado, Manado.

Lamb, A. \& Rodda, M., 2016, A guide to hoyas of Borneo, Natural History Publications Borneo, Kota Kinabalu.

Manzano, E.D.L., Andrade, J.L., Zotz, G., Reyes, G.C., 2014, Epiphytic orchids in tropical dry forests of Yucatan, Mexico - Species occurrence, abundance and correlations with host tree characteristics and environmental conditions, Flora 209, 100-109.

Mardiyana, M., Murningsih, M., \& Utami, S., 2019, Inventarisasi anggrek epifit (Orchidaceae) di hutan Peungkriyono, Pekalongan, Jawa Tengah [Inventory of epiphytes orchids (Orchidaceae) in Petungkriyono Forest, Pekalongan, Central Java]. Jurnal Akademika Biologi 8(2), 1-7

Ministry of Agriculture. 1979. Decree number 762/ Kpts/um/12/1979 about the appointment of Bawean Island forests covering an area of 4556.6 Ha located in Gresik regency, East Java Province as forest in EastJava as Nature Preserve Forests Cq. Nature Reserve covering an area of 725 ha and Wildlife area of 3381.6 hectares.

Maurizio, B. \& Salla, G., 1992., A new sub species of Atrophoneura coon from Bawean Island (Indonesia) Lepidoptera - Papilionidae, Tropical Lepidoptera 3(2), 119-128.

Nijman, V., 2004, Survey on birds of prey and owls (Falconiformes and Strigiformes) on Bawean Java Sea with records of three species new to the island, Raffles Bull Zool 52(2), 647-651.

Nurfadilah, S., 2016, Diversity of epiphytic orchids and host trees (phorophytes) in secondary forest of Coban Trisula, Malang Regency, East Java, Indonesia, Biotropia 22(2), 120-128.

Nurfadilah, S., Yulia, N. D., \& Ariyanti, E. E., 2016, Morphology, anatomy, and mycorrhizal fungi colonization in roots of epiphytic orchids of Sempu Island, East Java, Indonesia, Biodiversitas 17(2), 592-603.
Panajon, N.M., Aurigue, F.B., Shen, C.C., Ragasa, C.Y., 2016, Triterpenes and sterols from Hoya diversifolia Blume, J App Pharm Sci 6(6), 79-82.

Puspitaningtyas, D. M., 2007, Inventarisasi anggrek epifit dan inangnya di Taman Nasional Meru Betiri [Orchid Inventory and the host in Meru Betiri National Park, East Java]. Biodiversitas 8 (3), 210-214.

Rademaker, M., Meijaard, E., Semiadi, G., Blokland, S., Neilson, E. W., \& Rode-Margono, E. J., 2016, First ecological study of the Bawean warty pig (Sus blouchi), one of the rarest pigs on earth, PloS one 11(4), 1-15.

Rahayu, S., Fakhrurrozi, Y., \& Putra, H. F., 2018, Hoya species of Belitung Island, Indonesia, utilization and conservation, Biodiversitas 19(2), 369-376.

Rahayu, S., \& Rodda, M., 2019, Hoya of Sumatra, an updated checklist, three new species, and a new subspecies, European Journal of Taxonomy 508, 1-23.

Rahman, D. A., Gonzalez, G., \& Aulagnier, S., 2017, Population size, distribution and status of the remote and critically endangered Bawean deer Axis kublii, Oryx 51(4), 665-672.

Rahman, D. A., Gonzalez, G., Haryono, M., Muhtarom, A., Firdaus, A. Y., \& Aulagnier, S. 2017, Factors affecting seasonal habitat use, and predicted range of two tropical deer in Indonesian rainforest, Acta Oecologica 82, 41-51.

Sadili, A., 2019, Struktur, distribusi, dan pola tata ruang anggrek epifit (Orchidaceae) hutan pantai Cagar Alam Pulau Sempu [Structure, distribution, and spatial patterns of epiphytic orchids (Orchidaceae) at coastal forest of the Sempu Island Nature Reserve, Malang, East java]. Jurnal Ilmu Kehutanan 13(1), 38-47.

Semiadi, G., Duckworth, J.W., Timmins, R., 2015, 'Axis kublii' in The IUCN Red List of Threatened Species 2015, viewed 24 March 2020 from http://dx.doi.org/10.2305/ IUCN.UK.2015-2.RLTS.T2447A73071875.en. [26 August 2016].

Suita, E, 2012, Forest crop seed technology series: kesambi (Schleichera oleosa MERR.), Balai Penelitian Teknologi Perbenihan Tanaman Hutan, Bogor.

Sujalu, A. P. 2018. Identifikasi pohon inang epifit di hutan dataran rendah klimaks, Kabupaten Malinau [Identification of epiphytes host trees in climax Dipterocarpaceae lowland forest, Malinau District]. Jurnal Hutan Tropis 1(2), 196201. 
Sulaeman, M., Sulistijorini, S., \& Rahayu, S., 2019, Habitat suitability for Hoya spp. (Apocynaceae) in the Bodogol Conservation Area, West Java. Biosaintifike 11(1), 91-99.

Sulistiarini, D., \& Djarwaningsih, T., 2017, Keragaman anggrek di Cagar Alam Gunung Tukung Gede, Serang, Banten [Diversity of orchids in Gunung Tukung Gede Nature Reserve, Serang, Banten]. Jurnal Biodjati 2(1), 72-82.

Tang, D., Zhang, Q., Xu, L., Guo, D., \& Luo, Z., 2019, Number of species and geographical distribution of Diospyros L.(Ebenaceae) in China, Horticultural Plant Journal 5(2), 59-69.

Trimanto \& Hapsari, L., 2016, Botanical survey in thirteen montane forests of Bawean Island Nature Reserve, East Java Indonesia: flora diversity, conservation status, and bioprospecting, Biodiversitas 17(2), 832-846.

Trimanto, 2013, Keragaman pohon sekitar mata air di Pulau Moyo, Nusa Tenggara Barat [Diversity of trees around springs flow in the Moyo Island Region of West Nusa Tenggara]. Proceedings of National Conference of Biology 10(2), 15-23.

Trimanto. 2014. Analisis vegetasi dan estimasi stok karbon 7 gunung di suaka alam Pulau Bawean [Vegetation analysis and estimation of tree carbon stock biomass in seven mountain forests, Bawean Island Nature Reserve, East Java]. Berita Biologi 13 (3), 321-332.

Trimanto T., \& Sofiah, S., 2018, Exploration of flora diversity and recommending species for reclamation of coal mining with biodiversity concept in Besiq Bermai Forest, East Borneo, Journal of Tropical Life Science 8(2), 97-107.

Umiyah, Yulia, N.D., and Prasetyani, D., 2011, Inventarisasi anggrek epifit dan pohon inangnya di Cagar Alam Pulau Sempu, Kabupaten Malang, Jawa Timur [Inventory of epiphytic orchid species and its host trees in Sempu Island Nature Reserve, Malang District, East Java]. Proceeding of Na-tional
Conference "Tropical Plant Conservation: "Current condition and the next challenge", 475-478.

Vincen, N., 2004, Survey on birds of prey and owls (Falconiformes and Strigiformes) on Bawean Java Sea with records of three species new to the island, The Raffles Bulletin of Zoology 52 (2), 647-651.

Yubu, A., Pollo, H. N., \& Lasut, M. T., 2019, Inventarisasi anggrek hutan di taman wisata alam batuputih, kota bitung, sulawesi utara [Orchid inventory in Taman Batuputih Nature Tourism, Bitung City, North Sulawesi]. Eugenia 24(3), 116-122.

Yulia, N. D., 2010, Evaluasi keragaman anggrek di tiga kawasan hutan alam Jawa Timur Evaluation of orchid diversity on three forest area of East Java]. Berkala Penelitian Hayati Special Edition 4A, 41-44.

Yulia, N.D., Budiharta, S., 2011, Epiphytic orchids and host tree diversity at Gunung Manyutan Forest Reserve, Wilis Mountain, Ponorogo, East Java, Biodiversitas 12(1), 22-37.

Yulia, N.D., \& Budiharta, S., 2012, The diversity of epiphytic orchid and its phorophyte along cemoro sewu hiking pathway, Lawu Mountain, District of Magetan, East Java, Indonesia. Journal of Nature Studies 10(2), 26 -31.

Zanne, A.E., Lopez, G., Gonzalez , D.A., Coomes., J., Ilic., S., Jansen., S.L., Lewis., R.B., Miller., N.G., Swenson, Wiemann., M.C., and Chave, J., 2009, 'Irvingia malayana' in Global Wood Density Database, viewed 30 February 2020, from https://datadryad.org/stash/dataset/ doi:10.5061/dryad.234.html. 